\title{
PARTICULATE CONTAMINATION IN SELECTED PARENTERAL DRUGS
}

\author{
R. LEON LONGE
}

\section{Arstract $T$}

The particulate contamination of five frequently prescribed drugs was studied. Samples were obtained in a laminar flow workbench according to millipore technique. The dry sample filters were examined with a binocular microscope at $50 \mathrm{x}$ and $100 \times$. Particles were sized as to fibers, $>100$ microns, 51 to 100 microns, 25 to 50 microns, and 10 to 24 microns. The results show the variability of contamination. Particulate counts appear to correlate with the manufacturing process. Bulk powders are highly contaminated, followed by lyophilize powders, then stable solutions. Until the clinical importance is resolved and manufacturing processes improved, in-line filters may be of value in selected patients.

THL PROBLEM of particulate contamination in intravenous additives has been studied by several investigators. ${ }^{1.2}$ Although the U.S. Pharmacopeia continues to lack the strength needed to insure "good pharmaceutical practice," the U.S.P. states "Every care should be exercised in the preparation of all products intended for injection, to prevent contamination with microorganisms and foreign material." 3 The purpose of this study was to evaluate levels of particulate contamination in five selected intravenous additives.

\section{METHODOLOGY}

The products selected for the study are listed in Table I. Four samples of the same lot number were tested. Their selection was based on frequency of use in an intravenous additive service.

The "Analysis of Intravenous Solutions for Particulate Matter" (Millipore Corporation Application Report AR-2) procedure with modification was used in the study. All procedures were carried out in a laminar flow workbench. The equipment was precleaned and prepared according to AR-2 specifications.

Products requiring reconstitution were diluted according to manufacturers' requirements using a precleaned disposable syringe and Swinnex-25 filter. Prior to penetration of the vial, the needle was flushed with $2 \mathrm{ml}$ of filtered sterile water. The closure was wiped with a clean alcohol swab and rinsed with filtered isopropyl alcohol. After addition of the diluent, the needle was detached and the vial was shaken intermittently for 10 to 15

R. Leon Longe, Pharm.D., Assistant Professor, University of Georgia, School of Pharmacy, Athens, Georgia, 30602, U.S.A.

Canad. Anaesth. Soc. J., vol. 27, no. 1, January 1980 minutes. With a precleaned syringe, air was forced into the vial and the solution was withdrawn. The syringe was connected to the sample Swinnex-25 filter and a vacuum was applied. The vial was rinsed twice with $10 \mathrm{ml}$ of sterile filtered water. The sample filter was removed with clean forceps and placed into a petri slide, grid side up, and air dried in the laminar flow workbench. For solutions the same procedure was followed except for reconstitution. Blank analysis was run during each batch to judge effectiveness of cleaning.

The dry sample filter was examined with a binocular microscope at $50 \times$ and $100 \times$ with an illuminator at 10 to 20 degrees angle of incidence. Particles larger than 50 microns and fibers were counted by scanning the entire filter at $50 \times$ magnification. Particles were arranged into three ranges: 51-100 microns, greater than $100 \mathrm{mi}-$ crons, and fibers. Particles less than 50 microns were divided into 10 to 20 microns and 25 to 50 microns. Instead of counting the entire filter, seven randomly selected grid squares were used. The total for the two size ranges was statistically determined according to the AR-2 manual method.

\section{Results}

The results of the particle count clearly show the variability in levels of contamination (Table I). The results are a mean average particle count of four samples of each product. As can be seen, the powder products are significantly (Student's t-test, $p<0.05$ ) more contaminated than solutions. Most contaminants were sized at 10-24 microns. The methicillin product demonstrated the highest level of particles with most particles 
TABLE I

Mean Particle Count*

\begin{tabular}{|c|c|c|c|c|c|c|}
\hline & \multicolumn{4}{|c|}{$\operatorname{Sizc}(\mu)$} & \multirow[b]{2}{*}{ Fibers } & \multirow[b]{2}{*}{ Meantotal } \\
\hline & $10-24$ & $25-50$ & $51-100$ & $100+$ & & \\
\hline \multicolumn{7}{|l|}{ Solutions } \\
\hline $\begin{array}{l}\text { Aminuphylline } \dagger \\
500 \mathrm{mg} / 20 \mathrm{ml} \text { Ampul }\end{array}$ & 90 & 40 & 11 & 1 & - & 142 \\
\hline $\begin{array}{l}\text { Potassium Chloride } \dagger \\
40 \mathrm{mEq} / 20 \mathrm{ml} \text { Vial }\end{array}$ & 191 & 58 & 17 & 3 & - & 269 \\
\hline \multicolumn{7}{|l|}{ Powders } \\
\hline $\begin{array}{l}\text { Cephalothint } \\
4 \text { Grams Vial }\end{array}$ & 831 & 244 & 45 & 18 & 5 & 1143 \\
\hline $\begin{array}{l}\text { Methicillin }+ \\
4 \text { Grams Vial }\end{array}$ & 3062 & 186 & 75 & 22 & 9 & 3354 \\
\hline $\begin{array}{l}\text { Aqueous Potassium Penicillin G } \\
20 \text { Million Units Vial }\end{array}$ & 983 & 217 & 52 & 26 & 7 & 1285 \\
\hline \multicolumn{7}{|l|}{ Control } \\
\hline $\begin{array}{l}\text { Sterile Water } \\
20 \mathrm{ml}\end{array}$ & 10 & 2 & - & - & 1 & 13 \\
\hline
\end{tabular}

$* N=4$ Units of each product, $\uparrow$ Aqueous solution, $\ddagger$ Bulk powder.

sized between 10-24 microns. Glass particles were seen with the aminophylline product. Whereas fibers were absent from solutions but were present in powder drugs.

\section{Discussion}

Masuda and Beckerman, studying 12 injectable antibiotics, found particulate contamination depends on the manufacturing process. This study supports their conclusion. Sterile bulk fill products (cepalothin, methicillin, penicillin $G$ ) have a higher level of contamination than stable solutions (potassium chloride, aminophylline).

Six sources of contamination have been identified: (1) the active drug and adjuvants, (2) the container and component parts, (3) administration devices, (4) manipulations during preparation and administration, (5) manufacturing process, and (6) chemical reactions between the drug and container components. ${ }^{6}$ These potential particle-generating sources make identification a very complex problem. Rinaldi warns of the dangers of glass fragments from glass ampuls during myelography and ventriculography with iophendylate. ${ }^{7}$ Glass fragments were seen in the ampul product as a source of contamination. Fibers, seen in powder products and blank control, could have been from the reconstitution and the manufacturing processes. A positive source identity for other particles could not be established from viewing under magnification by the investigator.
The clinical significance of particulate matter is not clearly established. Capillaries are approximately $7-12$ microns in diameter; therefore, a particle larger than 12 microns may lodge and lead to occlusion. As shown in this study, a large number of particles were found to be greater than 10 microns. Animal studies show results of silicosis, platelet aggregation, reflex vasoconstriction, and pulmonary granulomatous inflammation, ${ }^{9,10}$ In patients, the harmful effects of particles were shown to occur in the lungs following intravenous therapy and in the cerebral circulation after angiography. " At autopsy, 25 of 545 premature infants were found to contain cotton fibers in branches of the pulmonary artery. ${ }^{12}$ Duma viewed asbestos fibers as "unpalatable and unacceptable" while urging industry to remove such fibers from their final product. ${ }^{3}$ The studies to date have not clearly documented that the particles in parenterals are clinically significant. However, the problem should be viewed as potentially hazardous to the patient until clinical studies prove otherwise.

\section{Conclusion}

Powder products appear to contain more particles $\geq 10$ microns and fibers than stable solutions. Glass ampuls upon opening create glass fragments. In-line filters effectively remove these contaminates. Attachment of a filter could be determined by the manufacturing; that is, pa- 
tients receiving bulk fill powder products (e.g. methicillin) and drugs from glass ampuls probably warrant filtration whereas lyophilize powders and stable solution in vials probably do not require filtration. Besides the additives products, numerous other factors contribute to generating particles, such as administration device, increasing number of additives, total volume administered and long term parenteral therapy. Inline filters are fraught with problems. ${ }^{14}$ The official compendia (e.g., United States Pharmacopeia) do not clearly define acceptable particulate levels. Filters may not be the best answer to the particulate problem but it is the interim solution until good manufacturing standards are established and/or the clinical significance is resolved.

\section{REFERENCES}

1. Gross, M.A. The danger of particulate matter in solutions for intravenous use. Drug Intelligence /: 12(1967).

2. Davis, H.M., Turco, S. \& Sivelly, E. A study of particulate matter in I.V. infusion fluids. American Journal of Hospital Pharmacy 27: 822 (1970).

3. Heller, W. The United States Pharmacopcia, 19th ed. Pennsylvania: Mack Printing Company (1975).

4. ANON. Millipore corporation application report: AR-2 analysis of intravenous solutions for particulate matter. Bedford, Mass. (1967).

5. Masuda, J.Y. \& Beckerman, J.h. Particulate matter in commercial antibiotic injectable products. American Journal of Hospital Pharmacy 30 : 72 (1973).

6. ANON. Proceeding of the FDA Symposium on the Safety of Large Volume Parenteral Solutions, Washington, D.C., July 28-29, 1966.

7. Rivalo1, I. Contamination of iophendylate by glass, New England Journal of Medicine, 300: 95 (1979).

8. Brewer, J.H. \& DunNing. J.H. An in vitro and in vivo study of glass particles in ampules. Journal of the American Pharmaceutical Association 36: 289 (1947).

9. NIDEN, A.H. \& AVIADO, D.M. Effects of pulmonary embolism on the pulmonary circulation with special reference to arteriovenous shunts in the lung. Circulation Research 4: 67 (1956).

10. Garvan, J.M. \& Gunner. B.W. The harmful effects of particles in intravenous hluids. Medical Journal of Australia 2: 1 (1964).

II. Sarrut, S. \& Nezelod, C. Une complication de la therapeutique intraveineuse. Presse Medicale 68 : 375 (1960).

12. Duma, R.J. Particulate matter of particular interest. Annals of Internal Medicine 78: 146 (1973).

\section{RÉSUMÉ}

La contamination de cinq produits d'usage courant par les particules a été étudiée. Des échantillons ont été obtenus d'un courant laminaire selon la technique Millipore. Les filtres assèchés ont été examinés au microscope binoculaire à $50 \mathrm{x}$ et $100 \times$. Les particules ont été classifées en fibres de plus de 100 microns, de 51 à 100 microns et de 10 à 24 microns. Ces résultats montrent la variabilité de la contamination. Le décomple des particules semble en corrélation avec le procédé de fabrication. Les poudres en vrac sont hautement contaminées, suvies des poudres lyophilisées et ensuite des solutions stables. En attendant que l'importance clinique de ces données soit reconnue et que le procédé de fabrication amélioré, on devrait peut-être utiliser des filtres pour certains patients. 